\title{
Methodical Learning on Organ Donation: Effect on Students Knowledge and Attitude
}

\author{
Maninder Singh ${ }^{1}$, Manpreet Kaur Grewal ${ }^{1}$, Amanpreet Kaur ${ }^{1}$, \\ Yamini Chopra $^{2}$, Aarti Bhatt ${ }^{2}$, Tenzin Choden ${ }^{2}$,Manisha Sharma ${ }^{2}$ \\ ${ }^{1}$ Assitant Professor, ${ }^{2}$ B.Sc Nursing $4^{\text {th }}$ Year Student, Chitkara School of Health Sciences, \\ Chitkara University, Punjab, India
}

\begin{abstract}
Introduction: Organ donation provides the recipient with a second chance to live. Inappropriate knowledge and attitude of individuals to organ donation are one of the most important barriers for organ donation.
\end{abstract}

Aims and Objectives: To determine the effectiveness of structured teaching program on knowledge and attitude regarding organ donation among students.

Study Design: Pre-experimental one group pre-test and post-test.

Study Variables: Age, Religion, Habitat, Family type,Education stream, and Information source.

Result and Discussion: It was found that after a structured teaching program knowledge level of students in post-test was increased that is $66 \%$ adequate knowledge whereas $34 \%$ of participants have moderate knowledge. Also, in pre-test $89 \%$ of the student had poor attitude and $79 \%$ student had satisfactory attitude in post-test. Significant association between the level scoreof knowledge with an information source had been found.

Conclusion: In the present study, a marked increase in knowledge and change in the attitude level of the students has been observed during the post test.

Keywords: Organ donation, knowledge, attitude.

\section{Introduction}

Organ Donation is the caring demonstration of giving one's organs to someone else, who is in critical need of those organs. It is characterized by the WHO as "giving human cells, tissues, and organs proposed for human applications". Giving an organ can prompt

\section{Corresponding Author:}

\section{Mr. Maninder Singh}

Assistant Professor, Department of Nursing, Chitkara

School of Health Sciences, Chitkara University, Punjab, India

e-mail: manindersodhi87@gmail.com

Mob. No.: 9988263329 sparing as well as improving the quality of life of someone else. Shockingly, the quantity of individuals that need an organ incredibly outperforms the quantity of genuine givers. ${ }^{[1]}$

In the world, India's organ donation rate is the lowest rate that is 0.86 per million. In India, 500,000 individuals need organ transplantation every year and a large number of them pass on because of an absence of organs accessible for transplantation. ${ }^{[2]}$ Lack of mindfulness alongside myths and misguided judgments adds to the low level of organ donation. Young adults address the inevitable destiny of society and effect family members and partners. A bit of good data on the young adults in this issue, not just method a constructive faculty disposition towards organ donation yet it can in like manner be the choosing part for supporting gifts when faced with the death of a relative. ${ }^{[3]}$ 
Along these lines, there is an incredible requirement for expanding mindfulness about the significance of organ donation and the lawful arrangements identified with it. Understudies are youngsters who spread information, deprived for mindfulness as a rule open intrigue. So an organized instructing program was intended to be regulated among the University understudies to expand the information level by mediations.

\section{Aims and Objectives:}

1. To assess the mean pre and post-test of Knowledge and attitude score regarding organ donation.

2. To determine the effectiveness of structured teaching program on the mean knowledge and attitude scores.

3. To determine the association between knowledge and attitude regarding organ donation with selected socio-demographic variables.

4. To find out the relationship between knowledge and attitude regarding organ donation among students.

\section{Material and Method}

Study Design: This was a Pre-experimental one group pre-test and post-test study conducted on 100 students studying at Chitkara University, Punjab, India. Sampling technique used for the data collection is Purposive sampling Technique. Structured knowledge Questionnaire used for assessing the knowledge of students and 3 point Likert's scale was used for assessing the Attitude of the students. First Pre-test was conducted on students after that organized instructing programme was administered to the students immediately after this. Post-test had been conducted after 7 days and the collected data was analyzed with the help of SPSS.
Inclusion Criteria: Students who were studying at Chitkara University and want to be a part in study.

Exclusion Criteria: Those were not present during data collection.

Study Variables: The variables were Age, Religion, Gender, Family type, Education stream, Habitat, Information source.

\section{Results and Discussion}

The total 100 students were participated in structured teaching program regarding organ donation at Chitkara University Punjab. Table-1 depictsmaximum (90\%) students were in the age of 18-21 years, followed by age up to -22 years $(10 \%)$. Majority of the sample were found to be females $(76 \%)$ whereas males were $(24 \%)$. In religion wise distribution it was found that there were Hindu (57\%), Muslim (6\%) and Christian (4\%).In relation to family it was found to be nuclear $(65 \%)$ and joint $(29 \%)$ and single parents $(6 \%)$.Data presented in above table shows greater $(73 \%)$ of students were form urban whereas $(27 \%)$ rural area. Regarding previous board of school more than half $(69 \%)$ of students were done schooling from private whereas (31\%) were done from government. In case of experience of organ donation data presented in above table shows lesser have $(7 \%)$ have experience of organ donation and greater have no personal/family experience of organ donation (93\%). Table show bulk of students haven't attended any organ donation program previously (81\%) and $(19 \%)$ have attended. The sample were found to be getting information from internet/mass media (46\%) and friends/family and health personnel (23\%) and any other $(8 \%)$.

Table 1: Frequency distribution of the level of knowledge of participants in pre-test \& post-test. $\mathrm{N}=100$

\begin{tabular}{|l|c|c|c|c|c|}
\hline & $\begin{array}{c}\text { Inadequate Knowledge } \\
(\mathbf{0 - 6})\end{array}$ & $\begin{array}{c}\text { Moderate Knowledge } \\
\mathbf{( 7 - 1 2 )}\end{array}$ & $\begin{array}{c}\text { Adequate Knowledge } \\
(\mathbf{1 3 - 1 7 )}\end{array}$ & Mean Score & SD \\
\hline Pre Test & $1(1 \%)$ & $62(62 \%)$ & $37(37 \%)$ & 11.96 & 2.146 \\
\hline Post Test & $0(0 \%)$ & $34(34 \%)$ & $66(66 \%)$ & 12.91 & 1.531 \\
\hline
\end{tabular}

Table 1 shows that there is difference between posttest mean (12.91) and pretest mean (11.96) knowledge regarding organ donation. 
Table 2: Association between Knowledge levels with demographic variables $\mathrm{N}=100$

\begin{tabular}{|c|c|c|c|c|c|c|}
\hline \multicolumn{2}{|l|}{ Demographic Variables } & \multicolumn{3}{|c|}{ Pre-Test Knowledge } & \multirow[b]{2}{*}{ Chi Test } & \multirow[b]{2}{*}{ P Value } \\
\hline Variables & Options & $\begin{array}{c}\text { Adequate } \\
\text { Knowledge }\end{array}$ & $\begin{array}{c}\text { Moderate } \\
\text { Knowledge }\end{array}$ & $\begin{array}{l}\text { Inadequate } \\
\text { Knowledge }\end{array}$ & & \\
\hline \multirow{2}{*}{ Gender } & Male & 12 & 12 & 0 & \multirow{2}{*}{2.492} & \multirow{2}{*}{$0.288^{\mathrm{NS}}$} \\
\hline & Female & 25 & 50 & 1 & & \\
\hline \multirow{5}{*}{ Age (in years) } & 18 Years & 6 & 15 & 0 & \multirow{5}{*}{5.985} & \multirow{5}{*}{$0.649^{\mathrm{NS}}$} \\
\hline & 19 Years & 14 & 26 & 0 & & \\
\hline & 20 Years & 13 & 15 & 1 & & \\
\hline & 21 Years & 3 & 6 & 0 & & \\
\hline & 22 Years & 1 & 0 & 0 & & \\
\hline \multirow{4}{*}{ Religion } & Hindu & 19 & 38 & 0 & \multirow{4}{*}{3.968} & \multirow{4}{*}{$0.681^{\mathrm{NS}}$} \\
\hline & Muslim & 2 & 4 & 0 & & \\
\hline & Christian & 1 & 3 & 0 & & \\
\hline & Sikh & 15 & 17 & 1 & & \\
\hline \multirow{3}{*}{ Family type } & Joint Family & 11 & 17 & 1 & \multirow{3}{*}{3.659} & \multirow{3}{*}{$0.454^{\mathrm{NS}}$} \\
\hline & Nuclear Family & 25 & 40 & 0 & & \\
\hline & Single Parent & 1 & 5 & 0 & & \\
\hline \multirow{2}{*}{ Habitat } & Urban & 25 & 47 & 1 & \multirow{2}{*}{1.172} & \multirow{2}{*}{$0.557^{\mathrm{NS}}$} \\
\hline & Rural & 12 & 15 & 0 & & \\
\hline \multirow{2}{*}{ Previous board of school } & Government & 10 & 21 & 0 & \multirow{2}{*}{0.961} & \multirow{2}{*}{$0.618^{\mathrm{NS}}$} \\
\hline & Private & 27 & 41 & 1 & & \\
\hline \multirow{2}{*}{$\begin{array}{l}\text { Personal/family experience of } \\
\text { organ donation }\end{array}$} & Yes & 3 & 4 & 0 & \multirow{2}{*}{0.174} & \multirow{2}{*}{$0.917^{\mathrm{NS}}$} \\
\hline & No & 34 & 58 & 1 & & \\
\hline \multirow{2}{*}{$\begin{array}{l}\text { Have you attended any organ } \\
\text { donation program previously }\end{array}$} & Yes & 6 & 12 & 1 & \multirow{2}{*}{4.455} & \multirow{2}{*}{$0.108^{\mathrm{NS}}$} \\
\hline & No & 31 & 50 & 0 & & \\
\hline $\begin{array}{l}\text { Information source of organ } \\
\text { donation }\end{array}$ & Friends/family & 7 & 16 & 0 & 14.799 & $0.022 *$ \\
\hline
\end{tabular}

$\mathrm{NS}=$ non-significant at $\mathrm{p}<0.05$ level

Table 2 describes that chi square test for association with the gender $(\chi 2=2.492)$, with age $(\chi 2=5.985)$, with religion $(\chi 2=3.968)$, with type of family $(\chi 2=3.659)$, with habitat $(\chi 2=1.172)$, with previous board of school, $(\chi 2=0.961)$ with personal/family experience of organ donation $\left(\chi^{2}=0.174\right)$, with have you attended any organ donation program previously related to knowledge $\left(\chi^{2}=4.455\right)$ and association with information of organ donation $(\chi 2=14.799)$.
The chi square value describes a significant association between level of knowledge score and information source $(p<0.05)$. There is no significant association between level of knowledge score and other socio demographics profile. 
Table 3: Association between attitude score with their socio demographic variables of the subjects $\mathrm{N}=100$

\begin{tabular}{|c|c|c|c|c|c|c|}
\hline \multicolumn{2}{|l|}{ Demographic Variables } & \multicolumn{3}{|c|}{ Pre-Test Attitude } & \multirow[b]{2}{*}{ Chi Test } & \multirow[b]{2}{*}{ P Value } \\
\hline Variables & Options & Poor Attitude & $\begin{array}{c}\text { Satisfactory } \\
\text { Attitude }\end{array}$ & Good Attitude & & \\
\hline \multirow{2}{*}{ Gender } & Male & 19 & 5 & & \multirow{2}{*}{3.119} & \multirow{2}{*}{$0.07^{\mathrm{NS}}$} \\
\hline & Female & 70 & 6 & & & \\
\hline \multirow{5}{*}{ Age (in years) } & 18 Years & 19 & 2 & & \multirow{5}{*}{1.606} & \multirow{5}{*}{$0.808^{\mathrm{NS}}$} \\
\hline & 19 Years & 35 & 5 & & & \\
\hline & 20 Years & 25 & 4 & & & \\
\hline & 21 Years & 9 & 0 & & & \\
\hline & 22 Years & 1 & 0 & & & \\
\hline \multirow{4}{*}{ Religion } & Hindu & 52 & 5 & & \multirow{4}{*}{3.883} & \multirow{4}{*}{$0.274^{\mathrm{NS}}$} \\
\hline & Muslim & 4 & 2 & & & \\
\hline & Christian & 4 & 0 & & & \\
\hline & Sikh & 29 & 4 & & & \\
\hline \multirow{3}{*}{ Family type } & Joint Family & 24 & 5 & & \multirow{3}{*}{2.103} & \multirow{3}{*}{$0.349^{\mathrm{NS}}$} \\
\hline & Nuclear Family & 59 & 6 & & & \\
\hline & Single Parent & 6 & 0 & & & \\
\hline \multirow{2}{*}{ Habitat } & Urban & 65 & 8 & & \multirow{2}{*}{0.000} & \multirow{2}{*}{$0.983^{\mathrm{NS}}$} \\
\hline & Rural & 24 & 3 & & & \\
\hline \multirow{2}{*}{ Previous board of school } & Government & 25 & 6 & & \multirow{2}{*}{3.203} & \multirow{2}{*}{$0.073^{\mathrm{NS}}$} \\
\hline & Private & 64 & 5 & & & \\
\hline \multirow{2}{*}{$\begin{array}{l}\text { Personal/family experience of } \\
\text { organ donation }\end{array}$} & Yes & 5 & 2 & & \multirow{2}{*}{2.374} & \multirow{2}{*}{$0.123^{\mathrm{NS}}$} \\
\hline & No & 84 & 9 & & & \\
\hline \multirow{2}{*}{$\begin{array}{l}\text { Have you attended any organ } \\
\text { donation program previously }\end{array}$} & Yes & 18 & 1 & & \multirow{2}{*}{0.789} & \multirow{2}{*}{$0.375^{\mathrm{NS}}$} \\
\hline & No & 71 & 10 & & & \\
\hline $\begin{array}{l}\text { Information source of organ } \\
\text { donation }\end{array}$ & Friends/family & 23 & 0 & & 5.405 & $0.144^{\mathrm{NS}}$ \\
\hline
\end{tabular}

$\mathrm{NS}=$ non-significant at $\mathrm{p}<0.05$ level

Table 3 delineates that chi square test for association with the gender $(\chi 2=3.119)$, with age $(\chi 2=1.606)$ with religion $(\chi 2=3.883)$, with type of family $(\chi 2=2.103)$, with habitat $(\chi 2=0.000)$, with previous board of school, $(\chi 2=3.203)$ with personal/family experience of organ donation $(\chi 2=2.374)$, with have you attended any organ donation program previously related to knowledge $(\chi 2=0.789)$ and association with information source of organ donation $(\chi 2=5.405)$.

The chi square value shows there is no any significant association between attitude score and other socio demographic profile. 
Table 4: Relationship between knowledge and attitude regarding organ donation among subjects $\mathbf{N}=100$

\begin{tabular}{|l|c|c|c|c|}
\hline Pair 1 & vs & Pair 1 & r value & P value \\
\hline Pre Knowledge & vs & Pre Attitude & 0.025 & 0.803 \\
\hline Post Knowledge & vs & Post Attitude & $0.244^{*}$ & 0.015 \\
\hline
\end{tabular}

*Correlation is significant at the 0.01 level (2-tailed).

Table 4 illustrates that there has been no relationship between pre knowledge and pre attitude but there is relationship between post knowledge and post attitude knowledge after structured teaching program.

\section{Conclusion}

Based on the present study knowledge level of students increases after structured teaching and also change in attitude level. There was significant association between level score of knowledge with information source whereas no statistically significant association was found with demographic variables.

\section{References}

1. Devi, S. and Jyothi, B., 2019. Effectiveness of Structured Teaching Programme on Knowledge and Attitude regarding Organ Donation and Transplantation among Adolescents in Selected Junior Colleges of Guntur (Dt), AP. International Journal of Advances in Nursing Management, 7(1), p.45.

2. Organ receiving and giving awareness network. Available from: https://www.organindia.org/makea-pledge/[Accessed 19 March 2020].

3. Beth, M. Baby, A. and Bhula, M., 2018. Effectiveness of Planned Teaching Programme on Knowledge Regarding Organ Donation Among Under Graduate Students. Journal of Advanced Health Informatics, 4(1). 